\title{
OFERTA I REKLAMA JAKO FORMA ROZPOWSZECHNIANIA UTWORU W ŚWIETLE ART. 4 UST. 1 DYREKTYWY 2001/29/WE - OCZYWISTOŚĆ CZY DYLEMAT?
}

\section{PRAWO ROZPOWSZECHNIANIA UTWORU A ZAKRES INNYCH PRAW WŁASNOŚCI INTELEKTUALNEJ}

Artykuł 4 ust. 1 dyrektywy 2001/29/WE ${ }^{1}$, nakazujący wyposażenie autorów w monopol na ,jakąkolwiek formę publicznego rozpowszechniania” utworu, wskazuje, że chodzi o rozpowszechnianie „w drodze sprzedaży lub w inny sposób”. W przepisach dotyczących innych praw własności intelektualnej, jak wynalazki, wzory użytkowe i przemysłowe, znaki towarowe i oznaczenia geograficzne, mówi się w tym kontekście o „oferowaniu” czy samym „używaniu” produktów zawierających chronione rozwiązanie ${ }^{2}$ lub „posługiwaniu się nimi w celu reklamy”3 albo ogólnie o „wszelkim bezpośrednim lub pośrednim wykorzystywaniu w celach komercyjnych" ${ }^{4}$. Również w przepisach o wyczerpaniu tych praw wskazuje się na „oferowanie do sprzedaży” jako działanie zastrzeżone dla uprawnionego ${ }^{5}$. Wobec tego pojawia się pytanie, czy do ,jakiejkolwiek formy publicznego rozpowszechniania” utworu „w drodze sprzedaży lub w inny sposób”, należącej w myśl art. 4 ust. 1 dyr. 2001/29 do wyłącznej kompetencji

${ }_{1}$ Dyrektywa nr 2001/29/WE Parlamentu Europejskiego i Rady z 22 maja 2001 r. w sprawie harmonizacji niektórych aspektów praw autorskich i pokrewnych w społeczeństwie informacyjnym, Dz. Urz. L 167, s. 10-19 (dalej jako: dyr. 2001/29).

2 Por. art. 12 ust. 1 dyrektywy Parlamentu Europejskiego i Rady nr 98/71/WE z 13 października 1998 r. w sprawie prawnej ochrony wzorów (Dz. Urz. L 289, s. 28-35) oraz art. 19 ust. 1 rozporządzenia Rady (WE) nr 6/2002 z 12 grudnia 2001 r. w sprawie wzorów wspólnotowych (Dz. Urz. L 3, s. 1-24), a w prawie polskim - art. 105 ust. 3 ustawy z 30 czerwca 2000 r. - Prawo własności przemysłowej, t.jedn.: Dz. U. 2014, poz. 1410 (dalej jako: p.w.p.).

${ }^{3}$ Por. art. 5 ust. 3 lit. b i d dyrektywy Parlamentu Europejskiego i Rady nr 2008/95/WE z 22 października 2008 r. mającej na celu zbliżenie ustawodawstw państw członkowskich odnoszących się do znaków towarowych, Dz. Urz. UE L 299, s. 25-33 (dalej jako: dyr. 2008/95) oraz art. 9 ust. 2 lit. b i d rozporządzenia Rady (WE) nr 207/2009 z 26 lutego 2009 r. w sprawie wspólnotowego znaku towarowego, Dz. Urz. L 78, s. 1-42 (dalej jako: rozp. 207/2009), a w prawie polskim - art. 154 pkt 1 i 3 p.w.p.

${ }^{4}$ Por. art. 13 ust. 1 lit. a rozporządzenia Rady (WE) nr 510/2006 z 20 marca 2006 r. w sprawie ochrony oznaczeń geograficznych i nazw pochodzenia produktów rolnych i środków spożywczych, Dz. Urz. L 93, s. 12-25.

${ }_{5}^{5}$ Por. w prawie polskim np. art. 70 i art. 155 ust. 1 p.w.p. 
autora, zalicza się ofertę sprzedaży lub tė̇ dokonaną w takim celu reklamę. Preambuła tej dyrektywy nie daje na nie jasnej odpowiedzi. Wprawdzie w świetle motywu 28 zd. 1-2 preambuły ochrona prawa autorskiego rozciagga się na prawo „kontrolowania dystrybucji utworu”, które sięga do „pierwszej sprzedaży”, kiedy doznaje wyczerpania. Niemniej na tle art. 4 ust. 1 dyr. 2001/29 otwarte pozostaje pytanie, jakie działanie podejmowane $\mathrm{w}$ związku ze sprzedażą lub innym sposobem rozpowszechnienia utworu należy zaliczyć do „jakichkolwiek” jego form.

\section{PROBLEM NA WAGE SPRAWY PRZED TRYBUNAŁEM SPRAWIEDLIWOŚCI UNII EUROPEJSKIEJ}

\section{Uwaga wstępna}

Powyższe zagadnienie okazuje się problematyczne. Stało się ono przedmiotem sporu przed niemieckim Sądem Najwyższym, który zwrócił się do Trybunału Sprawiedliwości Unii Europejskiej (TSUE, Trybunał) o udzielenie na nie odpowiedzi. Niedawno zaś została opracowana opinia rzecznika ${ }^{6}$.

\section{Pytania prejudycjalne}

Pytania skierowanie w tej sprawie do Trybunału mają szerszy kontekst rynkowy. Wymagaja wyjaśnienia, czy prawo do rozpowszechniania z art. 4 ust. 1 dyr. 2001/29 obejmuje uprawnienie do publicznego oferowania do nabycia oryginału lub kopii utworu (pyt. nr 1), a jeśli tak, to czy takie uprawnienie obejmuje też reklamę utworu (pyt. nr 2). Ponadto wymagaja wyjaśnienia, czy prawo do rozpowszechniania zostaje naruszone również wtedy, gdy na podstawie oferty nie dochodzi do nabycia egzemplarza utworu (pyt. nr 3).

\section{Krajowe tlo prawne}

Określone wyżej pytania sformułowano na tle dwóch przepisów niemieckiego prawa autorskiego ${ }^{7}$. Zgodnie z nimi twórcy przysługuje wyłączne prawo korzystania z utworu w postaci materialnej, które w szczególności, oprócz prawa do zwielokrotnienia i do wystawienia, obejmuje „prawo do rozpowszechniania” (§ 15 ust. 1), polegajace na „prawie do publicznego oferowania i wprowadzania do obrotu oryginału lub kopii utworu” (§ 17 ust. 1).

${ }^{6}$ Opinia rzecznika generalnego P. Cruza Villalóna z 4 grudnia 2014 r. w sprawie C-516/13, Dimensione Direct Sales srl, Michele Labianca przeciwko Knoll International Spa.

7 Ustawa z 9 września 1965 r. o prawie autorskim i prawach pokrewnych, BGBl. 1965, t. I, s. 1273 ze zm. 


\section{Motywy przyjęcia sprawy do rozstrzygnięcia}

Rzecznik zauważył, że wykładnia art. 4 ust. 1 dyr. 2001/29 w odniesieniu do pojęcia publicznego rozpowszechniania chronionych utworów była już przedmiotem rozważań Trybunału ${ }^{8}$. Jednak okoliczności faktyczne leżące u podstaw rozważanej sprawy różnią się od napotykanych we wcześniejszych postępowaniach. Uzasadniają one więc uściślenie ram ww. pojęcia.

\section{Okoliczności faktyczne sprawy}

Spór przed niemieckim SN powstał na skutek kasacji wniesionej przez włoską spółkę Dimensione Direct Sales, w której członkiem zarządu jest Michele Labianca. Dimensione sprzedaje w Europie meble designerskie w sposób bezpośredni oraz oferuje je na stronie internetowej dostępnej m.in. w języku niemieckim. W latach 2005-2006 spółka ta zamieszczała reklamy swojej oferty w niemieckich czasopismach, a także w prospekcie reklamowym z adnotacją: „Meble nabywacie już we Włoszech, płatności dokonujecie jednak przy odbiorze lub dostawie przez firmę spedycyjną uprawnioną do jej pobrania (na życzenie zostanie przez nas wskazana)".

Kasacja ta była wynikiem przegranych przez skarżących postępowań przed sądami w Hamburgu z pozwu włoskiej spółki Knoll International, należącej do międzynarodowej grupy Knoll. Pozew zawierał żądanie zakazania skarżącym oferowania do sprzedaży w Niemczech mebli niepochodzacych od grupy Knoll, a będacych reprodukcją mebli autorstwa Marcela Breuera i Ludwiga Miesa van der Rohe. Grupa Knoll produkuje i sprzedaje bowiem na całym świecie meble zaprojektowane przez tych twórców, które są chronione jako dzieła sztuki użytkowej. Powódka zaś ma wyłączne prawo korzystania z nich i upoważnienie do dochodzenia odnośnych roszczeń.

\section{Stanowisko sądu wnioskującego i stron}

W ocenie niemieckiego SN wszystkie pytania wymagają odpowiedzi twierdzącej, gdyż:

a) jednym z celów dyr. 2001/29 jest zapewnienie wysokiego poziomu ochrony prawa autorskiego, wobec czego wykładnia art. 4 ust. 1 tej dyrektywy powinna być szeroka;

b) wyłączne prawo do ,jakiejkolwiek formy publicznego rozpowszechniania” utworu „w drodze sprzedaży lub w inny sposób” powinno obejmować ofertę sprzedaży, a więc nie tylko ofertę zawarcia umowy, lecz również reklamę;

c) powinno tak być również wtedy, gdy w wyniku ww. działań nie dojdzie do nabycia egzemplarza utworu, co powoduje, że ofertę należy w tym przypadku rozumieć w sensie ekonomicznym, a nie prawnym, który odpowiada pojęciu „oferta umowy”, co oznacza, że działania reklamowe zachęcające do nabycia

${ }^{8}$ Wskazał on na dwa wyroki: z 17 kwietnia 2008 r. w sprawie C-M456/06, Peek \& Cloppenburg KG przeciwko Cassina Spa, Zb. Orz. 2008, s. I-2731, i z 21 czerwca 20012 r. w sprawie C-M5/11, Titus Donner, nieopubl. w Zb. Orz. 
stanowią same w sobie publiczną ofertę objętą prawem do rozpowszechniania w rozumieniu art. 4 ust. 1 dyr. 2001/29;

d) takiej wykładni nie sprzeciwia się wyrok w sprawie Peek\&Cloppenburg, w którym TSUE orzekł, że w zakres powyższego pojęcia wchodzą tylko działania wymagające przeniesienia własności, ponieważ nie można z niego wnosić, że prawo do rozpowszechniania na podstawie ww. przepisu nie obejmuje działania przygotowawczego do takiego przeniesienia, oferta sprzedaży utworu jest bowiem powiązana z przeniesieniem własności, gdyż go dotyczy;

e) ponadto w wyroku w sprawie Donner TSUE orzekł, że handlowiec, który kieruje reklamę do klientów z określonego państwa i udostępnia im szczególny system dostawy i zapłaty lub zezwala na takie działanie osobie trzeciej, umożliwiając dostawę na rzecz tych klientów kopii utworów chronionych w tym państwie, dokonuje w państwie, w którym dostawa miała miejsce, „publicznego rozpowszechniania" w rozumieniu ww. przepisu.

Skarżący sprzeciwili się powyższej ocenie, motywując swoje stanowisko tym, że:

a) w przypadku zwykłej oferty nie może być mowy o rozpowszechnianiu w rozumieniu art. 4 ust. 1 dyr. 2001/29 „w drodze sprzedaży” ani „w inny sposób”, jeśli bowiem w wyroku w sprawie Donner TSUE wzią pod uwagę działania reklamowe, to tylko jako wskazówkę w ocenie zamiaru zwrócenia się przez handlowca do klientów z państwa, w którym rozpowszechnianie rzeczywiście miało miejsce;

b) wymóg szerokiej wykładni pojęcia rozpowszechniania celem zapewnienia ochrony podmiotów praw autorskich (zwłaszcza ich interesów handlowych) jest więc bezpodstawny, jeśli oferta nie powoduje nabycia, ponieważ w tym przypadku podmiot taki nie doznaje szkody, a zatem nie będzie miał prawa do odszkodowania;

c) nie jest też konieczne rozszerzenie pojęcia rozpowszechniania dla zakazania działań reklamowych, ponieważ art. 9 ust. 1 lit. a dyrektywy 2004/48 o egzekwowaniu praw własności intelektualnej ${ }^{9}$ umożliwia wystawienie przez sąd tymczasowego nakazu mającego zapobiec dalszym naruszeniom ${ }^{10}$, co oznacza, że działania poprzedzające naruszenie mogą zostać zakazane bez potrzeby uznania ich samych za naruszajace te prawa.

Natomiast grupa Knoll poparła ocenę sądu, choć tylko co do samych wniosków, ponieważ:

a) pytanie, czy można zakazać reklamy jako naruszającej wyłączne prawo do rozpowszechniania w rozumieniu art. 4 ust. 1 dyr. 2001/29, opiera się na

9 Dyrektywa nr 2004/48/WE Parlamentu Europejskiego i Rady z 29 kwietnia 2004 r. w sprawie egzekwowania praw własności intelektualnej, Dz. Urz. L 157, s. 45-86 (dalej jako: dyr. 2004/48).

${ }^{10}$ Zgodnie z tym przepisem sąd może wystawić przeciwko domniemanemu naruszycielowi tymczasowy nakaz, który ma zapobiec możliwym dalszym naruszeniom prawa własności intelektualnej, lub w razie kontynuowania domniemanych naruszeń, tymczasowo tego zakazać i w miarę potrzeb poddać powtarzającej się karze pieniężnej, jeśli prawo krajowe taką przewiduje, lub nakazać złożenie zabezpieczenia zapewniającego pokrycie strat poniesionych przez właściciela praw, a także może wystawić tymczasowy nakaz przeciwko pośrednikowi, którego usługi są wykorzystywane przez osobę trzecią do naruszania prawa własności intelektualnej. 
błędnej, gdyż zbyt wąskiej interpretacji zakresu tego prawa przyjętej w wyroku w sprawie Peek\&Cloppenburg;

b) w istocie TSUE orzekł $\mathrm{w}$ tym wyroku, że na mocy wyłącznego prawa do rozpowszechniania podmiot praw autorskich dysponuje jedynie prawem do kontrolowania przeniesienia własności utworu z wyłączeniem wszelkich innych uprawnień, a taka wykładnia nie uwzględnia celu dyr. 2001/29;

c) skoro pytania w obecnej sprawie podnoszą kwestię, czy zgodnie z prawem międzynarodowym art. 4 ust. 1 dyr. 2001/29 przewiduje zharmonizowaną ochronę maksymalna, czy tylko minimalna, to zatwierdzony przez UE traktat o prawie autorskim ${ }^{11}$ nie może być interpretowany jako naruszajacy prawa zagwarantowane przez przepisy krajowe, w tym przez $§ 17$ ust. 1 ustawy niemieckiej, przyznający podmiotowi praw autorskich wszystkie możliwe prawa do korzystania z utworu, w związku z czym art. 4 ust. 1 dyr. 2001/29 według wykładni zgodnej z tym traktatem nie może ograniczać praw, z których autorzy korzystali już w państwach członkowskich przed przyjęciem tej dyrektywy;

d) na pytania te należy więc odpowiedzieć tak, że przewidziane w ww. przepisie prawo do rozpowszechniania obejmuje prawo do publicznego oferowania utworu, które rozciaga się zarówno na ofertę sprzedaży, jak i na działania reklamowe, oraz że prawo to zostaje naruszone również wtedy, gdy na podstawie oferty nie dochodzi do nabycia utworu, a w każdym razie, że przepis ten nie stoi na przeszkodzie ustawodawstwu krajowemu, które przyznaje takie prawo.

\section{Stanowisko pozostałych uczestników}

Rząd hiszpański też opowiedział się za taką odpowiedzia, ale przy innej argumentacji:

a) jakkolwiek w świetle wyroku w sprawie Donner nie można mówić o rozpowszechnianiu utworu bez umowy sprzedaży i dostawy przedmiotu sprzedaży kupującemu, to jednak w przypadku sprzedaży niezbędne jest, aby umowa została zaoferowana publicznie, a w związku z tym prawo do rozpowszechniania powinno obejmować ofertę umowy jako element przygotowawczy, niezbędny dla każdej umowy sprzedaży;

b) wobec tego prawo do rozpowszechniania obejmuje nie tylko ofertę sprzedaży, lecz również reklamę, w zakresie, w jakim przez swój cel wpisuje się ona w łańcuch czynności przygotowawczych do sprzedaży produktu i w jakim sprzedaż byłaby bez niej niemożliwa;

c) skoro zatem oferta następuje w ramach kanału dystrybucji specjalnie przeznaczonego do nabycia przedmiotów objętych ochroną prawnoautorska, co wiąże się z działaniem skierowanym do konkretnego klienta, to prawo do

11 Decyzja Rady nr 2000/278/WE z 16 marca 2000 r. w sprawie zatwierdzenia w imieniu Wspólnoty Europejskiej Traktatu WIPO o prawie autorskim oraz Traktatu WIPO o artystycznych wykonaniach i fonogramach, Dz. Urz. L 89, s. 6 (dalej odpowiednio, jako: „TPA” i „TAWF”). Zob. też Traktat Światowej Organizacji Własności Intelektualnej o prawie autorskim, sporządzony w Genewie 20 grudnia 1996 r., oraz Oświadczenie rządowe z 28 października 2004 r. w sprawie mocy obowiązującej tego Traktatu, Dz. U. 2005, Nr 3, poz. 12 i 13. 
rozpowszechniania utworu może zostać naruszone przy braku rzeczywistej sprzedaży takich przedmiotów.

Tymczasem stanowisko Komisji Europejskiej było zmienne, ponieważ:

a) początkowo uznała ona, że w świetle wyroków w sprawach Peek\& Cloppenburg i Donner rozpowszechnianie w rozumieniu art. 4 ust. 1 dyr. 2001/29 zakłada sprzedaż lub inną formę przeniesienia własności i taka zawężająca wykładnia pojęcia rozpowszechniania, wyłączająca z niego operacje poprzedzające zawarcie umowy sprzedaży, nie stoi w sprzeczności z celem realizowanym przez tę dyrektywę;

b) ostatecznie zaś przyjęła, że wykluczenie każdej oferty sprzedaży z pojęcia rozpowszechniania może tworzyć lukę w ochronie podmiotów praw autorskich, ponieważ po stwierdzeniu sprzedaży nie mogliby oni korzystać ze środków przewidzianych w dyr. 2004/48, wobec czego wykładnia tego pojęcia, obejmująca niektóre oferty, jest możliwa pod dwoma warunkami: 1) że taka możliwość zostanie dookreślona, a kryteria oferty wynikające z prawa do rozpowszechniania zostana zdefiniowane przez Trybunał oraz 2) że wykładnia ust. 1 i 2 art. 4 dyr. 2001/29 zostanie rozdzielona, a zatem, że o ile zwykła ofertę można ewentualnie uznać za objętą ust. 1, niezależnie od rzeczywistego aktu przeniesienia własności, o tyle nie można traktować jej jako powodującej wyczerpanie się prawa w rozumieniu ust. 2 .

\section{Opinia rzecznika generalnego}

\subsection{Zastrzeżenia formalne}

Rzecznik zwrócił najpierw uwagę na formalne okoliczności sprawy, a mianowicie, że:

1) Knoll domaga się zakazania Dimensione zgodnie z prawem niemieckim oferowania do sprzedaży chronionych tym prawem reprodukcji mebli niepochodzących od grupy Knoll, ale podstawą tego żądania nie są dokonane akty sprzedaży, a ponadto środek stanowiący przedmiot takiego żądania w świetle wniosku prejudycjalnego - co jednak nie zostało określone przez Knoll ani przez sąd wnioskujaccy - miałby polegać na zakazaniu takiej sprzedaży za pośrednictwem strony internetowej, jak i szerzej, gdyż także przez działania reklamowe;

2) niniejsza sprawa różni się zatem od wcześniejszych sporów o wykładnię art. 4 ust. 1 dyr. 2001/29 rozstrzygniętych przez Trybunał, ponieważ w sprawie tej sprzedaż lub dostawa mebli nie została stwierdzona i Dimensione ma dopiero zamiar w tym względzie, podczas gdy:

- w wyroku w sprawie Peek\&Cloppenburg chodziło o wystawienie na widok publiczny reprodukcji mebli chronionych prawem autorskim oraz umożliwienie korzystania z nich bez ich sprzedaży lub nawet zamiaru sprzedaży;

- natomiast w wyroku w sprawie Donner, jak i podobnym wyroku w sprawie Blomquist ${ }^{12}$, meble były już przedmiotem sprzedaży lub dostawy albo próby dostawy;

12 Wyrok z 6 lutego 2014 r. w sprawie C-98/13, Martin Blomqvist przeciwko Rolex SA, Manufacture des Montres Rolex SA, nieopubl. w Zb. Orz., który dotyczył zastosowania rozp. 1383/2003 w sprawie działań organów celnych i środków wobec towarów naruszających prawa własności 
3) niemniej w świetle przedstawionych okoliczności nie jest tu możliwe udzielenie odpowiedzi na pytanie prejudycjalne nr 2, ponieważ:

- we wniosku niemiecki SN przedstawił lakoniczne informacje o działaniach reklamowych Dimensione, a przy tym nie przedstawił powodów, dla których odpowiedź na to pytanie miałaby być niezbędna do rozstrzygnięcia tej sprawy i uznania żądań Knoll;

- wobec wspomnianych braków nie da się stwierdzić w ww. zakresie konieczności wykładni prawa UE przydatnej dla sądu krajowego, a celem wniosku prejudycjalnego nie jest wydanie opinii o charakterze doradczym w odpowiedzi na ogólne lub hipotetyczne pytania, lecz potrzeba skutecznego rozstrzygnięcia sporu dotyczącego prawa UE;

- dlatego udzielenie odpowiedzi na powyższe pytanie jest niedopuszczalne i pozostaje rozważyć sprawę jedynie w zakresie pytań nr 1 i 3.

\subsection{Stanowisko merytoryczne}

Rzecznik przypomniał przede wszystkim, że jakkolwiek w wyroku w sprawie Peek\&Cloppenburg Trybunał stwierdził, że art. 4 ust. 1 dyr. 2001/29 ani żaden inny jej przepis nie precyzuja pojęcia publicznego rozpowszechniania utworu, to podkreślił w nim, potwierdzając to w wyroku w sprawie Donner, że ww. pojęcie należy interpretować - jeśli to możliwe - w świetle postanowień wspomnianego TPA. Wskazana dyrektywa ma bowiem na celu wdrożenie zobowiązań podjętych przez Wspólnotę na podstawie tego traktatu i w tym też zadaniem art. 4 dyr. 2001/29 jest wdrożenie art. 6 TPA. A ponieważ w ust. 1 tego przepisu TPA w definicji prawa do wprowadzenia utworu do obrotu określa się publiczne udostępnianie utworu jako „sprzedaż lub inną formę przeniesienia własności”, więc pojęcie rozpowszechniania w drodze „sprzedaży lub w inny sposób” z art. 4 ust. 1 dyr. 2001/29 należy interpretować tak samo, tj. jako akt przeniesienia własności.

Rzecznik zaznaczył jednak, odwołując się do wyroku w sprawie Donner, że pojęciu „rozpowszechniania” w rozumieniu art. 4 ust. 1 dyr. 2001/29 należy nadać autonomiczną wykładnię w prawie UE, niezależną od prawa mającego zastosowanie do transakcji, w ramach których doszło do rozpowszechnienia. Ponadto, odwołując się też do wyroku w sprawie Blomqvist, dodał, że publiczne rozpowszechnianie to szereg następujacych po sobie transakcji, od zawarcia umowy sprzedaży do jej wykonania w drodze dostawy do klienta. Definicje przyjęte przez Trybunał należy więc postrzegać w ich kontekście. Nie można ich interpretować jako sprzeciwiających się temu, aby naruszenie prawa do rozpowszechniania było możliwe w braku faktycznej sprzedaży, jeśli tylko w danym przypadku transakcje ewentualnie zakazane na podstawie tego prawa wpisują się w kontekst wyraźnie sprzyjajacy zawarciu umowy sprzedaży.

Rzecznik wyjaśnił, nawiązując do opinii rzecznika w sprawie Donner ${ }^{13}$, że pojęcie rozpowszechniania „w drodze sprzedaży” powinno być interpreto-

intelektualnej (zob. dalej) do sytuacji, w której osoba zamieszkała w państwie członkowskim nabyła na użytek prywatny podrabiany zegarek za pośrednictwem strony internetowej sprzedawcy z państwa trzeciego (zob. dalej).

${ }^{13}$ Opinia rzecznika generalnego N. Jääskinena z 29 marca 2012 r. w sprawie C-5/13, Titus Donner. 
wane w sposób dający autorom skuteczną kontrolę nad komercjalizacją ich utworów, począwszy od ich reprodukcji, poprzez handel, aż do wyczerpania prawa. Komercjalizacja taka może dotyczyć dokonanej bez zezwolenia uprawnionego oferty sprzedaży lub każdej oferty za pośrednictwem strony internetowej, która udostępnia klientom instrumenty umożliwiające zapłacenie za zakup i dostarczenie egzemplarzy chronionych utworów. Jeżeli bowiem strona taka funkcjonuje jako handlowa, prowadząc (stale, czasowo czy też jednorazowo) sprzedaż przedmiotów chronionych prawem autorskim, przedstawiając ich szczegółowe dane oraz informując o warunkach ich zakupu i dostawy, to należy uznać, że świadczy ona o zamiarze ustanowienia kanału dystrybucji tych przedmiotów, który podlega zakazowi z art. 4 ust. 1 dyr. 2001/29.

W okolicznościach przedmiotowej sprawy zamiar wprowadzenia do obrotu kopii chronionych utworów przez osoby odpowiedzialne za stronę internetowa jest zatem wystarczająco oczywisty, a prawdopodobieństwo, że sprzedaż była lub będzie rzeczywiście zrealizowana, jest wystarczająco istotne, aby właściciele praw do tych utworów mogli wyegzekwować uniemożliwienie takiej sprzedaży na podstawie ich wyłącznego prawa do rozpowszechniania, w szczególności, aby mogli domagać się przyjęcia środków na podstawie wspomnianej dyr. 2004/48 (art. 6) ${ }^{14}$ w celu przedstawienia niezbędnych dowodów. W tym kontekście należy też odrzucić argument, że nie jest konieczne szerokie rozumienie prawa do rozpowszechniania z art. 4 ust. 1 dyr. 2001/29, gdyż na podstawie dyr. 2004/48 sądy mają możliwość wydania względem domniemanych naruszycieli nakazów tymczasowych, mających zapobiec ryzyku dalszych naruszeń praw własności intelektualnej. Przedstawione pytania dotyczą bowiem istoty prawa do rozpowszechniania, a nie przepisów proceduralnych służących uniemożliwieniu wszelkich dalszych naruszeń. Jak zresztą zauważono w sprawie Donner, odnosi się to w tym samym kontekście również do invitatio ad offerendum, a nawet do reklamy adresowanej do docelowego odbiorcy, o ile następują one za pośrednictwem lub w związku ze stroną internetowa z oczywistym zamiarem współdziałania przy zawieraniu umów sprzedaży egzemplarzy utworów lub zdecydowanego przyczynienia się do przeniesienia ich własności.

W ocenie rzecznika w odpowiedzi na pytania prejudycjalne należałoby więc stwierdzić, że prawo do rozpowszechniania w rozumieniu art. 4 ust. 1 dyr. 2001/29 obejmuje prawo do zakazania każdemu przez podmiot praw do chronionego utworu publicznego oferowania jego oryginału lub kopii do sprzedaży bez zezwolenia również wtedy, gdy na podstawie tej oferty nie dochodzi do ich nabycia, o ile następuje ona z wyraźnym zamiarem zawarcia umów sprzedaży lub innego aktu przeniesienia własności.

\footnotetext{
${ }^{14}$ Zgodnie z tym przepisem, w razie przedstawienia należytych dowodów na poparcie roszczeń i wskazania na potwierdzające je dowody u strony przeciwnej, sąd może nakazać przedstawienie takich dowodów przez tę stronę, pod warunkiem zapewnienia ochrony informacji poufnych, a w razie naruszenia na skalę handlową, sąd może, w miarę potrzeby, nakazać przekazanie przez nią dokumentów bankowych, finansowych lub handlowych.
} 


\section{ZNACZENIE POWYŻSZEGO PROBLEMU W PRAWIE UE NA TLE ORZECZNICTWA TRYBUNAEU}

\section{Uwaga wstępna}

Należy się spodziewać, że Trybunał w przyszłym wyroku w przedmiotowej sprawie podzieli stanowisko rzecznika. Przewidywanie takie ma oparcie w praktyce stosowania art. 4 ust. 1 dyr. 2001/29, jaka wynika z cytowanych wyżej wyroków TSUE i opinii rzeczników. Jedyne, czego można by jeszcze oczekiwać od Trybunału, to uproszczenie przyjętego w tej opinii kryterium charakteru działania poprzedzającego sprzedaż lub inną transakcję przeniesienia własności oryginału lub kopii utworu z punktu widzenia związu takiego działania z realizacją wspomnianego skutku. Chodzi o kryterium „wyraźnego zamiaru” w przypadku oferty czy też reklamy ${ }^{15}$ dotyczącej ww. transakcji. Kryterium to jest nieostre. Ponadto nie występuje ono w przypadku tych samych działań, które względem innych praw własności intelektualnej (jak znak czy wzór) są traktowane jako formy publicznej eksploatacji chronionych przez nie rozwiązań. Wystarczający do objęcia wyłącznością z tytułu takich praw jest zwykły zwiazek oferty lub reklamy z wprowadzeniem do obrotu towaru zawierającego chronione rozwiązanie. Związek ten wystapi już wtedy, gdy oferta lub reklama towaru objętego ochrona jest podejmowana z zamiarem jego sprzedaży lub innej transakcji przeniesienia własności, a nie - jak przyją rzecznik w odniesieniu do tego rodzaju działań względem towaru chronionego jako utwór - z zamiarem kwalifikowanym, odznaczającym się „wyraźnością”, „oczywistością" czy „zdecydowaniem”. Ten aspekt interpretacji pojęcia rozpowszechniania „w jakikolwiek w inny sposób” z art. 4 ust. 1 dyr. 2001/29 jest jednym z ważniejszych w kontekście ustaleń, jakie w tej kwestii zostały już przyjęte w praktyce unijnej, o której niżej.

\section{Sprawa Peek\&Cloppenburg}

Wyrok w sprawie Peek\&Cloppenburg był pierwszym dotyczacym zastosowania art. 4 ust. 1 dyr. 2001/29. Odnosił się do utworów w postaci mebli, których ochrona krajowa oparta była na przepisach niemieckich. Również sytuacja prawna pozwanej w wyżej omówionej sprawie była zbieżna z sytuacją pozwanej w niniejszej sprawie. Pozwana, spółka Cassina, była producentem mebli, zwłaszcza do siedzenia, w tym kolekcji mebli według projektu Le Corbusiera (właśc. Ch.-É. Jeanneret), wśród której znajdowały się fotele, kanapy oraz zestawy stołowe, wytwarzane i sprzedawane przez tę spółkę na podstawie posiadanej licencji. Natomiast skarżąca, spółka Peek\&Cloppenburg, prowadząca m.in. w Niemczech sklepy z odzieża, urządziła w nich kącik do odpoczynku dla klientów, wyposażony w komplet ww. mebli, a w witrynie umieściła dla dekoracji fotel z tej serii, które to meble zostały wytworzone bez zgody Cassiny przez spółkę włoska, którą notabene była firma Dimensione.

15 O ile w tym zakresie TSUE nie uchyli się - jak to proponuje rzecznik - od udzielenia odpowiedzi. 
Niemiecki SN rozpatrujący kasację skarżącej, która przegrała przed sądami we Frankfurcie nad Menem, powziął wattpliwości co do trafności takiego rozstrzygnięcia. Wystąpił więc do TSUE o wyjaśnienie, czy w przypadku umożliwienia osobom trzecim korzystania z reprodukcji chronionych utworów, jeżeli nie jest z tym związane przeniesienie własności lub posiadania zapewniającego rozporządzanie nimi, można mówić o jakiejkolwiek formie publicznego rozpowszechniania w inny sposób niż w drodze sprzedaży w rozumieniu art. 4 ust. 1 dyr. 2001/29, a także czy takie rozpowszechnianie występuje też wtedy, gdy te reprodukcje są pokazywane tylko dla dekoracji, czyli bez możliwości korzystania z nich.

Trybunał podzielił te wątpliwości. Stwierdził, że pojęcie publicznego rozpowszechniania utworu w inny sposób niż w drodze sprzedaży w rozumieniu ww. przepisu odnosi się wyłącznie do przeniesienia własności. Dlatego samo umożliwienie publiczności korzystania z reprodukcji chronionego utworu ani sam fakt ich wystawienia na widok publiczny, bez umożliwienia korzystania $\mathrm{z}$ nich, nie stanowi formy rozpowszechniania. Trybunał wskazał na motyw 15 preambuły dyr. 2001/29, przewidujący, że dyrektywa ta zmierza do wdrożenia niektórych zobowiązań międzynarodowych podjętych przez Wspólnotę na podstawie ww. traktatów. Przypominajac, że przepisy wspólnotowe, w szczególności te majace na celu wprowadzenie w życie umowy zawartej przez Wspólnotę, należy interpretować w świetle prawa międzynarodowego ${ }^{16}$, przyjął, że pojęcie rozpowszechniania z art. 4 ust. 1 dyr. 2001/29 należy interpretować na tyle, na ile jest to możliwe, w świetle definicji zawartych w TPA i TAWF. Artykuł 6 ust. 1 TPA oraz art. 8 i 12 TAWF definiuja zaś pojęcie prawa do wprowadzenia do obrotu (tj. rozpowszechniania) utworów lub fonogramów, przysługującego twórcom lub artystom wykonawcom i producentom, jako wyłączne prawo zezwalania na publiczne udostępnianie ich oryginału i kopii droga sprzedaży lub „innej formy przeniesienia własności”. Oznacza to, że w ww. traktatach pojęcie wprowadzenia do obrotu związane jest wyłącznie z przeniesieniem własności. Skoro więc art. 4 dyr. 2001/29 rządzi się tą samą logika, co art. 6 TPA, i jego celem jest wprowadzenie tego przepisu traktatu w życie (a obydwa przepisy regulują też jednakowo kwestię wyczerpania), to użyte w tym przepisie dyrektywy pojęcie „w drodze sprzedaży lub w inny sposób” należy interpretować, zgodnie z traktatem, jako formę rozpowszechniania wymagajaca przeniesienia własności.

Trybunał, negujacc, że w przedmiotowej sprawie miało miejsce przeniesienie własności mebli chronionych prawem autorskim, zauważył, że nie jest jego zadaniem ustanawianie na rzecz twórców nowych praw i rozszerzanie pojęcia rozpowszechniania utworu poza granice, które nie zostały przewidziane w dyr. 2001/29. Taka zmiana należy do prawodawcy, jeśli dojdzie on do przekonania, że obowiąujące uregulowania nie gwarantują ochrony twórców na wystarczająco wysokim poziomie i że takie korzystanie z utworu, jak to, którego dotyczy niniejsze postępowanie, należy uzależnić od zgody twórcy.

16 Wskazano tu na wyroki z 14 lipca 1998 r. w sprawie C-M341/95, Bettati, Zb. Orz., s. I-4355 (pkt 20) i z 7 grudnia 2006 r. w sprawie C-M306/05, SGAE, Zb. Orz., s. I-11519 (pkt 35). 
W świetle powyższego wyroku rzecznik w sprawie Dimensione Direct Sales miał podstawy do uznania, że postawione w niej pytania znalazły już swoja odpowiedź w tym wyroku. Było tak tym bardziej, że w opinii poprzedzającej wydanie wyroku rzecznik zają takie samo stanowisko ${ }^{17}$. Niemniej do zmiany takiej oceny skłoniło go rozstrzygnięcie zapadłe w analogicznej kwestii w późniejszej sprawie Donner.

Przed prezentacją tego rozstrzygnięcia warto jeszcze zwrócić uwagę na pogląd wyrażony w sprawie Peek\&Cloppenburg przez spółkę Cassina i popierający ją rząd polski, również będący uczestnikiem w tej sprawie. Domagali się oni szerszej wykładni pojęcia ,jakikolwiek inny sposób” sprzedaży, argumentując to w szczególności:

- motywami preambuły dyrektywy i otwartą formuła ww. pojęcia, przyznających szeroką ochronę twórcom dzieł;

- szeroką koncepcją prawa wprowadzania do obrotu, stosowana w innych regulacjach o prawach autorskich poprzedzajacych dyr. 2001/29, jak np. w dyrektywach o najmie i użyczeniu, ochronie prawnej programów komputerowych oraz ochronie prawnej baz danych ${ }^{18}$;

- szerokim rozumieniem „wprowadzania do obrotu” w wielu orzeczeniach Trybunału; ${ }^{19}$

- sprzecznościa wąskiej wykładni tego pojęcia z rozp. 1383/2003²0, która w przedmiotowej sprawie oznaczałaby, że towary pirackie pochodzace z (innych) państw członkowskich mogłyby zostać bez sankcji wwiezione do państw ochrony rozwiązań zawartych w takich towarach lub ponownie z nich wywiezione, a sankcje takie w postaci braku możliwości wwozu lub wywozu miałyby być stosowane tylko do towarów pirackich pochodzacych z państw trzecich (z uwagi na zastosowanie ww. rozporządzenia do tak określonej wymiany handlowej).

Rzecznik w opinii w tej sprawie zbił zaś ww. argumenty, przyjmujacc, że:

- z uwagi na charakter art. 4 ust. 1 dyr. 2001/29 jako przepisu majacego na celu wdrożenie art. 6 ust. 1 TPA definiującego prawo wprowadzania do obrotu jako prawo zezwalania na publiczne udostępnianie utworu „drogą sprzedaży lub innej formy przeniesienia własności”, a więc nieobejmującego udostępnia-

\footnotetext{
17 Opinia rzecznika generalnego E. Sharpston z 17 stycznia 2008 r. w sprawie C-M456/06, Peek\&Cloppenburg KG przeciwko Cassina $S p A$.

18 Przepisy te posługują się pojęciami „udostępniania w drodze sprzedaży lub w inny sposób”, „jakiejkolwiek formy publicznej dystrybucji” i „publicznego rozpowszechniania w jakiejkolwiek formie".

${ }^{19}$ Wymieniono tu wyroki z 17 maja 1988 r. w sprawie 158/86, Warner Brothers $i$ Metronome Video, Zb. Orz., s. 2605, z 28 kwietnia 1998 r. w sprawie C-M200/96, Metronome Musik, Zb. Orz., s. I-1953, i z 22 września 1998 r. w sprawie C-M61/97, Foreningen FDV, Zb. Orz., s. I-5171.

${ }^{20}$ Rozporządzenie Rady (WE) nr 1383/2003 z 22 lipca 2003 r. dotyczące działań organów celnych skierowanych przeciwko towarom podejrzanym o naruszenie niektórych praw własności intelektualnej oraz środków podejmowanych w odniesieniu do towarów, co do których stwierdzono, że naruszyły takie prawa (Dz. Urz. L 196, s. 7-14), a obecnie rozporządzenie Parlamentu Europejskiego i Rady (UE) nr 608/2013 z 12 czerwca 2013 r. w sprawie egzekwowania praw własności intelektualnej przez organy celne oraz uchylające rozporządzenie Rady (WE) nr 1383/2003, Dz. Urz. L 181, s. 15-34 (dalej odpowiednio jako: „rozp. 1383/2003” i „rozp. 608/2013”).
} 
nia do czasowego korzystania, tak samo należy rozumieć odpowiadające mu prawo publicznego rozpowszechniania z ww. przepisu dyr. 2001/29;

- jest tak tym bardziej, że obydwa przepisy dotyczą wyczerpania prawa, a zakres wyczerpania jest wyznaczony czynnościami rodzajowo zbliżonymi do aktów wprowadzania do obrotu;

- skoro we wspomnianych innych regulacjach o prawach autorskich, poprzedzających dyr. 2001/29, nie zdefiniowano pojęcia „wprowadzenia do obrotu”, to argument odsyłający do takich regulacji jest zbyt ogólnikowy;

- nieprzekonujące jest też odwoływanie się do motywów dyr. 2001/29, ponieważ uproszczeniem jest założenie, że wszelkie wątpliwości w zakresie pojęcia „wprowadzenia do obrotu” należy rozstrzygać na korzyść uprawnionego, a dotyczy to zwłaszcza sytuacji, gdy - jak w niniejszej sprawie - wykładnia oparta na takim założeniu byłaby sprzeczna z wyraźnymi przepisami TPA, majaccymi znaczenie dla wykładni tej dyrektywy;

- co się zaś tyczy powołanego orzecznictwa Trybunału, to dotyczyło ono prawa autora lub producenta do zezwalania na najem nagrań utworu muzycznego lub filmowego, a w szczególności jego sprzeczności z zasadą wyczerpania prawa wprowadzania do obrotu wraz z pierwszą sprzedażą oraz jego wyczerpania w całej Wspólnocie, gdy uprawniony zezwolił na najem tylko w jedynym państwie, które to kwestie Trybunał rozstrzygną przecząco z uwagi na szczególny charakter prawa najmu oraz odpowiednich rynków, wobec czego nie jest zrozumiałe, w jaki sposób rozstrzygnięcia w ww. sprawach miałyby pomóc w zdefiniowaniu „wprowadzania do obrotu” w odmiennej sytuacji w omawianej sprawie;

- tak samo niezrozumiałe sa zastrzeżenia co do wasskiego rozumienia form rozpowszechniania utworu z art. 4 ust. 1 dyr. 2001/29, oparte na skutkach takiej interpretacji dla stosowania rozp. 1383/2003, ponieważ meble nabyte przez Peek\&Cloppenburg we Włoszech nie były w tym państwie chronione jako utwory, a więc nie były towarami pirackimi, lecz były tam wyprodukowane i nabyte zgodnie $\mathrm{z}$ prawem.

\section{Sprawa Donner}

W sprawie tej podstawa prawną były przepisy krajowe, na których tle zapadł wyrok w sprawie Peek\&Cloppenburg i zostanie też wydany wyrok w sprawie Dimensione Direct Sales, a ponadto przepisy karne z niemieckiej ustawy o prawie autorskim ${ }^{21}$. Przedmiotem sporu była sprzedaż kopii utworu w państwie członkowskim nieudzielajaccym mu ochrony oraz transport tych kopii do innego państwa, w którym naruszenie prawa do utworu podlega sankcjom prawa karnego. Spór ten toczył się w trybie karnym przeciwko przewoźnikowi w związku z pomocnictwem w bezprawnym rozpowszechnianiu chronionych utworów. Przewoźnikiem była tu włoska spółka Inspem z jej prezesem Titusem Donnerem, który zarządzał nią z miejsca swego zamieszkania w Niemczech.

${ }^{21}$ Chodzi tu o przepisy zakazujące rozpowszechniania chronionych utworów bez zgody osoby, której prawo to przysługuje, w tym szczególnego przypadku takiego działania, którego dokonano w celach handlowych. 
Co ważne dla związku tej sprawy z obydwoma postępowaniami wskazanymi wyżej to fakt, że Inspem zapewniała transport mebli spółki Dimensione, oferującej klientom m.in. z Niemiec sprzedaż reprodukcji mebli przez ogłoszenia w czasopismach, bezpośrednią przesyłkę reklamową oraz niemieckojęzyczna stronę internetowa, nie posiadając przy tym licencji na sprzedaż tych towarów w Niemczech. Były to reprodukcje krzeseł i stolików znanych projektantów. Wśród nich były krzesła zaprojektowane przez Le Corbusiera, względem których posiadaczem licencji była notabene spółka Cassina. Meble takie klienci z Niemiec sprowadzali za pośrednictwem Inspem, która odbierała je we włoskim magazynie wytwórcy wraz z fakturą dla zamawiającego za zapłatą ceny sprzedaży, po czym w momencie dostawy - w zamian za wydanie faktury pobierała tę kwotę i koszt transportu od klienta. Do przeniesienia własności mebli ze sprzedawcy na nabywcę dochodziło więc w magazynie wytwórcy (na mocy prawa włoskiego) już w momencie przekazania do transportu, natomiast przeniesienie prawa do rozporządzania nimi następowało dopiero w chwili przekazania nabywcy w Niemczech (skutkującego przeniesieniem własności na mocy prawa niemieckiego).

Sądy w Monachium stwierdziły winę Donnera za pomocnictwo w handlowym wykorzystaniu chronionych utworów z naruszeniem przepisów niemieckich. Uznały one za bez znaczenia brak ochrony spornych mebli prawem autorskim we Włoszech w dacie ich sprzedaży przy współudziale Inspem. Sprzedaż ta była bowiem realizowana docelowo na rynku niemieckim, na którym taka ochrona była przyznana, wobec czego ograniczenie swobodnego przepływu towarów, wynikające z krajowych przepisów prawa autorskiego, było uzasadnione względami ochrony własności przemysłowej i handlowej. Donner nie zgodził się z taką ocena. Zauważył, że „publiczne rozpowszechnianie” w rozumieniu art. 4 ust. 1 dyr. 2001/29, a tym samym i odnośnego przepisu niemieckiego, oznacza przeniesienie własności, które w przedmiotowej sprawie miało miejsce we Włoszech. Przeniesienie posiadania, tj. rzeczywistego władztwa, nie było tu konieczne. Zresztą samo wydanie mebli spółce Inspem, która wykonywała ich dostawę na rachunek klientów niemieckich, stanowiło również przeniesienie posiadania, wobec czego nawet przy uwzględnieniu tej drugiej przesłanki należałoby przyjąć, że wszystkie okoliczności istotne dla stosowania przepisów niemieckich miały miejsce we Włoszech. Ponadto skazanie go na podstawie wykładni przeciwnej naruszałoby swobodę przepływu towarów (art. 34 i 36 TfUE) ${ }^{22}$, ponieważ wynikałby z niej sztuczny podział rynków.

Niemiecki SN podzielił pogląd sądów monachijskich, że „publiczne rozpowszechnianie” w drodze sprzedaży w rozumieniu art. 4 ust. 1 dyr. 2001/29 oznacza nie tylko, że dochodzi do przeniesienia na osobę trzecią własności kopii chronionego utworu, lecz także że osoba ta posiada rzeczywiste prawo

\footnotetext{
${ }^{22}$ Zgodnie z ww. przepisami Traktatu o funkcjonowaniu Unii Europejskiej, przyjętego na konferencji międzyrządowej, która przyjęła Traktat z Lizbony podpisany 13 grudnia $2007 \mathrm{r}$. (Dz. Urz. C 326, s. 47-200), zakazane są między państwami wszelkie ograniczenia ilościowe w przywozie i środki o skutku równoważnym (art. 34), co nie stanowi przeszkody w stosowaniu zakazów lub ograniczeń przywozowych, wywozowych lub tranzytowych uzasadnionych względami m.in. ochrony własności przemysłowej i handlowej, o ile nie powoduje to dyskryminacji ani ukrytych ograniczeń w handlu między państwami (art. 36).
} 
rozporządzania tą kopia. Niemniej przyją, że art. 34 i 36 TfUE mogą stanowić przeszkodę w utrzymaniu w mocy wyroku skazującego Donnera, jeśli stosowanie niemieckich przepisów karnych musiałoby zostać uznane w tej sprawie za nieuzasadnione ograniczenie swobody przepływu towarów. Dlatego zadał pytanie Trybunałowi, czy ww. przepisy TfUE sprzeciwiają się, aby pomocnictwo w niedozwolonym rozpowszechnianiu chronionych utworów podlegało karze w wyniku zastosowania przepisów krajowych, jeśli w przypadku transgranicznej sprzedaży chronionego utworu w Niemczech jednocześnie: a) utwór ten zostaje przywieziony z innego państwa do Niemiec i tu jest przenoszone rzeczywiste władztwo nad nim oraz b) przeniesienie własności następuje jednak w innym państwie, w którym utwór nie podlegał ochronie lub ochrona taka była niewykonalna.

W odpowiedzi na to pytanie TSUE zauważył, że wobec uznania za przesłankę niemieckich przepisów karnych istnienia na terytorium Niemiec „publicznego rozpowszechniania" w drodze sprzedaży w rozumieniu art. 4 ust. 1 dyr. 2001/29, konieczne jest uprzednie rozstrzygnięcie, czy w okolicznościach sprawy ma miejsce takie rozpowszechnianie. Powołując się na wyrok w sprawie Peek\&Cloppenburg w zakresie relacji między ww. przepisem i art. 6 TPA, potwierdził, że pojęcie „publiczne rozpowszechnianie w drodze sprzedaży” z pierwszego z tych przepisów ma to samo znaczenie, co wyrażenie „publiczne udostępnianie drogą sprzedaży” zawarte w drugim z nich. Wskazał, że pojęcie to wymaga w prawie Unii Europejskiej wykładni niezależnej od prawa mającego zastosowanie do transakcji, w ramach których doszło do rozpowszechnienia. Wykładnia ta każe dostrzec, że publiczne rozpowszechnianie charakteryzuje się szeregiem następujacych po sobie transakcji, od zawarcia umowy sprzedaży do jej wykonania w drodze dostawy do klienta. W razie sprzedaży transgranicznej, w której transakcje prowadzące do „publicznej sprzedaży” mają miejsce w kilku państwach, oznacza to, że taka transakcja może stanowić zagrożenie dla prawa do wszelkich form rozpowszechniania w kilku państwach. Handlowiec jest więc odpowiedzialny za każdą transakcję na swój rachunek prowadząca do „publicznego rozpowszechniania” w państwie członkowskim, gdzie rozpowszechniane towary sa chronione prawem autorskim, w tym za taka transakcję dokonana przez osobę trzecia, jeżeli ukierunkował się on na klientów państwa przeznaczenia tych towarów i nie mógł nie wiedzieć o działaniach owej osoby. Handlowiec, który kieruje swoją reklamę do klientów z określonego państwa i udostępnia im szczególny system dostawy oraz zapłaty lub zezwala na takie działanie osobie trzeciej, umożliwiając klientom dostawę na ich rzecz kopii utworów chronionych w tym państwie, dokonuje zatem w państwie, w którym dostawa miała miejsce, „publicznego rozpowszechniania" w rozumieniu art. 4 ust. 1 dyr. 2001/29.

$\mathrm{Na}$ zasadnicze pytanie Trybunał udzielił zatem odpowiedzi przeczacej. Uznał, że na tle art. 34 i 36 TfUE można ścigać na podstawie krajowego prawa karnego pomocnictwo w rozpowszechnianiu bez zezwolenia kopii chronionych utworów, w przypadku gdy kopie są publicznie rozpowszechniane przez sprzedaż rodzimym klientom, do której to sprzedaży dochodzi w innym państwie, gdzie kopie te nie są chronione lub na ich ochronę nie można się skutecz- 
nie powołać. Ograniczenie, które w przedmiotowej sprawie dotyka handlowca z siedzibą we Włoszech w związku z sankcjonowanym karnie zakazem rozpowszechniania w Niemczech, opiera się zresztą na rozbieżnościach w ochronie praw autorskich w tych państwach. Co więcej, ograniczenie to wynika ze stosowania przepisów, które są konieczne dla ochrony prawa do korzystania z utworu. Jest ono też proporcjonalne do zamierzonego celu, gdyż T. Donner świadomie ${ }^{23}$ uwikłał się w transakcje publicznego rozpowszechniania utworów na terytorium Niemiec, gdzie prawo autora mebli dostarczanych przez Inspem korzystało z ochrony.

Powyższe rozstrzygnięcie zapadło przy daleko idącym uwzględnieniu opinii rzecznika. Poczyniono w niej też szersze uwagi o rynkowym kontekście tego sporu, w myśl których:

- pojęcie ,jakakolwiek forma publicznego rozpowszechniania [...] w drodze sprzedaży lub w inny sposób” z art. 4 ust. 1 dyr. 2001/29 ma istotne konsekwencje dla stosunków handlowych na rynku wewnętrznym i zewnętrznym, ponieważ przepis ten harmonizuje występujący na poziomie krajowym zlepek przepisów dotyczących prawa do rozpowszechniania utworu;

- zakres dystrybucji na podstawie ww. przepisu ma wpływ na środki zaskarżenia dostępne dysponentowi prawa autorskiego w obrębie UE, jak i na ochronę dostępną na poziomie międzynarodowym wobec handlu podrobionymi towarami;

- co więcej, ranga ww. przepisu musi umożliwiać kontrolę zjawisk, które mogły zostać wykryte przez krajowe organy celne przed zniesieniem wewnątrzunijnych kontroli granicznych, a więc obowiązek UE i państw na podstawie porozumienia TRIPS ${ }^{24}$, polegajacy na zapobieganiu przywozom pirackich kopii chronionych utworów, znajdujących się w obrocie, nie może już być wykonywany środkami podejmowanymi przez organy celne, lecz powinien być realizowany za pomoca zharmonizowanego prawa autorskiego (tj. rozp. $1383 / 2003)^{25}$;

- ponadto w świetle najnowszych wyzwań, jakie stanowi handel elektroniczny, unijne reguły ochrony, takie jak ww. przepis, powinny być interpretowane w sposób, który wystarczająco zapewni, że prawa te będą w pełni chronione w erze Internetu;

- dotyczy to w szczególności ochrony w ramach prowadzonej przez Internet transgranicznej sprzedaży wysyłkowej, która w przypadku utworów ma-

${ }^{23}$ Początkowo bowiem dostawy mebli były prowadzone z Włoch do magazynu w Niemczech, a dopiero po zarzucie prokuratury niedozwolonego wykorzystywania chronionych utworów i umorzeniu postępowanie w zamian za zapłatę grzywny Inspem zaczął odbierać meble z magazynu Dimensione we Włoszech.

${ }^{24}$ Porozumienie w sprawie handlowych aspektów praw własności intelektualnej, stanowiące załącznik 1 C do Porozumienia ustanawiającego Światową Organizację Handlu, sporządzonego w Marrakeszu 15 kwietnia 1994 r. i zatwierdzonego decyzją Rady z 22 grudnia 1994 r. dotycząca zawarcia w imieniu Wspólnoty Europejskiej porozumień będących wynikiem negocjacji w ramach Rundy Urugwajskiej, Dz. Urz. L 336, s. 214-233.

${ }^{25}$ Art. 51 ww. porozumienia ustanawia prawo domagania się zaprzestania przywozu kopii naruszających prawa autorskie na terytorium ich ochrony, które jest wykonywane w ramach zewnętrznych kontroli celnych, ale nie oddziałuje na wewnątrzunijny przepływ towarów. 
terialnych prowadzi do tych samych rezultatów, co nadawanie (w tym przez Internet) utworów niematerialnych, a więc sytuacji skutkującej co najmniej ograniczoną eksterytorialnością jako wyjątek od terytorialnej ochrony dóbr intelektualnych (a sytuacja ta, obejmująca czynności częśsiowo wykonywane poza granicami kraju, zasługuje na ochronę, gdyż nie zawsze jest tak, że skutki rynkowe naruszenia oraz samo naruszenie mają miejsce w państwie ochrony - zgodnie z lex loci protectionis);

- tego rodzaju ochrona jest uzasadniona, gdyż działanie poza terytorium ochrony prawa, którego skutki nakierowane sa na to terytorium, należy do zakresu zharmonizowanego prawa własności przemysłowej, w tym ww. przepisu, a obok niego np. także przepisów o znakach ${ }^{26}$ :

- oznacza to, że wspomniana ochrona nie może być zależna od czynników cywilistycznych, takich jak wybór prawa dla pozaumownych zobowiązań dotyczących praw własności intelektualnej, decydującego o tym, czy i gdzie przez sprzedaż kopii chronionych utworów doszło do rozpowszechniania, ponieważ umożliwiałoby to obchodzenie praw autorskich (podstawowe znaczenie ma tu więc, czy sprzedawca stworzył ukierunkowane kanały sprzedaży i dostawy dla nabywcy utworu, w stosunku do którego prawa autorskie są chronione w państwie nabywcy, a sam sposób organizacji dostawy ma znaczenie drugorzędne);

- ochrona ta wymaga przyjęcia, że do rozpowszechniania utworu może dojść nie tylko wtedy, gdy transakcja przeniesienia własności została skutecznie zakończona, gdyż w przeciwnym razie oferowanie sprzedaży kopii chronionych utworów byłoby wyłączone z takiej ochrony;

- ochrona ta, mająca zapewniać autorom skuteczną kontrolę nad komercjalizacją ich utworów, wymaga zatem, aby rozpowszechnianie „w drodze sprzedaży” było interpretowane jako łańcuch czynności, począwszy od ich reprodukcji, poprzez handel, czyli oferowanie sprzedaży i zawieranie takich umów, aż do ich wykonania, czyli wyczerpania prawa autorskiego.

Po tych ustaleniach rzecznik w sprawie Dimensione Direct Sales mógł zweryfikować wnioski płynace z wyroku w sprawie Peek\&Cloppenburg i miał już prostszą drogę do stanowiska, jakie zają w swojej opinii. Było tak tym bardziej, że oferta sprzedaży została na tle art. 4 ust. 1 dyr. 2001/29 uznana już za formę rozpowszechniania „w drodze sprzedaży”, a nie za ów dalszy „inny sposób” rozpowszechniania. Przynajmniej w tym elemencie ww. sporu należy się więc spodziewać podzielenia tej opinii w przyszłym wyroku Trybunału.

\section{Sprawa Blomqvist}

Natomiast za podtrzymaniem w oczekiwanym wyroku w pełni interpretacji ww. przepisu dokonanej w tej sprawie przez rzecznika przemawiają ustalenia Trybunału w sprawie Blomqvist. Ustalenia te sa najbardziej istotne z punktu

${ }^{26}$ W wyroku z 12 lipca 2011 r. w sprawie C-M324/09, L’Oréal i in., Zb. Orz., s. I-6011, stwierdzono, że ochrona znaku wspólnotowego w przypadku oferowanych do sprzedaży towarów z podobnym znakiem pochodzących spoza EOG, a dostępnych w UE przez sprzedaż internetowa, jest zależna od ustalenia, czy oferta sprzedaży lub reklama online, dostępna na terytorium ochrony ww. znaku, jest skierowana do konsumentów na tym terytorium. 
widzenia pytania o dylemat, rozważanego w tym opracowaniu. Były one też potrzebne rzecznikowi w sprawie Dimensione Direct Sales, ponieważ rzecznik w sprawie Donner uznał, że sama reklama kopii utworów, nieodbiegająca od oferty sprzedaży, nie jest objęta prawem do rozpowszechniania, pomimo że na reklamę rozciaga się ochrona prawa do znaku towarowego ${ }^{27}$. A m.in. tej kwestii dotyczyła sprawa Blomqvist, w której opinię opracował rzecznik ze sprawy Dimensione Direct Sales.

W sprawie tej pytanie brzmiało, czy ww. przepis należy interpretować w taki sposób, że do „publicznego rozpowszechniania” towaru chronionego prawem autorskim dochodzi wtedy, gdy przedsiębiorca zawiera za pośrednictwem strony internetowej w państwie trzecim umowę sprzedaży i dostawy do klienta w państwie członkowskim, w którym towar jest chroniony tym prawem, otrzymuje zapłatę i wysyła towar, czy też w sytuacji takiej konieczne jest, aby sprzedaż była poprzedzona ofertą lub reklamą skierowaną do klientów w takim państwie albo umieszczona na stronie internetowej, której ci odbiorcy sa grupa docelowa. Pytanie to zmierzało do wyjaśnienia pojęcia „publiczne rozpowszechnianie" w rozumieniu art. 4 ust. 1 dyr. 2001/29 i zarazem pojęcia „używanie w obrocie handlowym” w rozumieniu przepisów o znakach, tj. art. 5 ust. 1 i 3 dyr. 2008/95 oraz art. 9 ust. 1 i 2 rozp. 207/2009, tak aby móc ocenić kwestię naruszenia prawa własności intelektualnej, potrzebną do zastosowania uprawnień z rozp. 1383/2003. Rozporządzenie to nie ustanawia bowiem nowego kryterium umożliwiającego ocenę naruszenia ww. praw ${ }^{28}$ i dlatego naruszenie takie może być podnoszone w celu interwencji organów celnych tylko wtedy, gdy sprzedaż towaru może wpływać na prawa przyznane przez odnośne przepisy, tj. dyr. 2001/29 lub dyr. 2008/95 i rozp. 207/2009. Chodziło więc o kwestię, czy wynika z niego, że do tego, aby posiadacz prawa własności intelektualnej do towaru, sprzedawanego drogą wysyłkową za pomoca strony internetowej znajdującej się w państwie trzecim, korzystał z ochrony zagwarantowanej przez to rozporządzenie w chwili wejścia towaru na obszar państwa członkowskiego, konieczne jest, aby sprzedaż była tu uznana za publiczne rozpowszechnianie lub za używanie w obrocie handlowym, oraz czy przed sprzedażą towar musi być tu objęty ofertą sprzedaży lub reklamą.

W tym kontekście Trybunał zestawił ze sobą zakresy ochrony omawianych kategorii praw własności intelektualnej. Przypomniał, że właściciel znaku jest uprawniony do zakazania używania oznaczenia identycznego dla towarów lub usług identycznych z tymi, dla których znak jest zarejestrowany, jeżeli używanie to ma miejsce w obrocie handlowym i może negatywnie wpływać na funkcje $\mathrm{znaku}^{29}$. Natomiast autorowi przysługuje prawo do zabraniania jakiejkolwiek

${ }^{27}$ Zob. pkt 54 opinii. W jej pkt 58 rzecznik przyznał zaś, że tak jak Trybunał w sprawie L'Oréal $i$ in. interpretował odnośne przepisy UE o znakach w celu ustalenia ukierunkowanego zachowania, to w przypadku art. 4 ust. 1 tej dyrektywy podobna interpretacja jest wymagana, „w szczególności w świetle wyzwania, jakie dla prawa własności intelektualnej stanowi reklama przez Internet”.

${ }^{28}$ Wyrok z 9 listopada 2006 r. w sprawie C-M281/05, Montex Holdings, Zb. Orz., s. I-10881 (pkt 40).

${ }^{29}$ Wyrok z 23 marca 2010 r. w sprawach połaczonych od C-M236/08 do C-M238/08, Google France $i$ Google, Zb. Orz., s. I-2417 (pkt 49). 
formy publicznego rozpowszechniania utworów w drodze sprzedaży lub w inny sposób, które charakteryzuje się ciagiem transakcji, od umowy sprzedaży do dostawy towaru do klienta, majacej miejsce w państwie ochrony ${ }^{30}$. Wobec tego Trybunał stwierdził, że prawo UE wymaga uznania występujacej w przedmiotowej sprawie sprzedaży za formę publicznego rozpowszechniania w rozumieniu dyr. 2001/29 oraz za formę używania w obrocie handlowym w rozumieniu dyr. 2008/95 lub rozp. 207/2009. Takie rozpowszechnianie występuje nie tylko w razie zawarcia umowy sprzedaży i jej realizacji w drodze dostawy, lecz już wcześniej. Jak bowiem podano wyżej, sprawa ta dotyczyła naruszenia praw własności intelektualnej względem zegarków. W zakresie praw do znaków była ona rozpatrywana na tle ustawy duńskiej odpowiadającej regulacji unijnej. Natomiast w zakresie prawa autorskiego była rozpatrywana na tle drugiej ustawy duńskiej ${ }^{31}$, regulującej prawo publicznego udostępniania utworu w sposób dalej idacy niż dyr. 2001/29. Podobnie bowiem jak w ustawie niemieckiej mającej zastosowanie m.in. w sprawie Dimensione Direct Sales, ustawa duńska w art. 2 ust. 1 i 3 pkt 1 i 3 za takie udostępnianie uważa zarówno „publiczne rozpowszechnianie” utworu w postaci oryginalnej lub zmienionej, jak i sytuację, w której „oferowana jest sprzedaż, wynajem lub użyczenie jego kopii lub sa one publicznie rozpowszechniane w inny sposób”. Wobec tych ustaleń Trybunał uznał, że w niniejszej sprawie firma Rolex, uprawniona w Danii do zegarków jako utworów i znaków, mogła powołać się na naruszenie swoich praw już wtedy, gdy podróbki zegarków zostały wystawione do sprzedaży przez handlowca z siedzibą w tym państwie, ponieważ w trakcie takiego rozpowszechniania tych towarów korzystał on z praw firmy Rolex.

Natomiast rozstrzygając, czy Rolex może dochodzić tej samej ochrony, gdy sporny towar został sprzedany drogą wysyłkową za pośrednictwem strony internetowej z państwa trzeciego, w którym nie stosuje się takiej ochrony, Trybunał przypomniał, że sama dostępność serwisu internetowego na terytorium, dla którego zastrzeżono znak, nie może wystarczać do wniosku, że wyświetlone w nim oferty sprzedaży są skierowane do konsumentów na tym terytorium ${ }^{32}$. Równocześnie jednak przyjął wcześniej, że może dojść do naruszenia tak chronionych praw, jeżeli towary z państw trzecich, objęte tą ochrona przed ich wjazdem na terytorium ochrony, są przedmiotem czynności handlowej skierowanej do konsumentów w UE, jak sprzedaż, jej oferta lub reklama. W ten sposób takie towary mogą naruszać prawa w UE do znaku lub utworu, a zatem zostać uznane za „podrobione” lub „pirackie” w rozumieniu rozp. 1383/2003, jeżeli zostanie udowodnione, że są one przeznaczone do wprowadzenia do obrotu w UE. Dowód taki zostaje przedstawiony, gdy okaże się, że towary zostały sprzedane klientowi w UE lub były przedmiotem skierowanej do niego oferty sprzedaży czy reklamy ${ }^{33}$. To, że w rozpoznawanej sprawie do

\footnotetext{
${ }^{30}$ Odwołano się tu do wyroku w sprawie Donner (pkt 26-27).

${ }^{31}$ Ustawa o prawach autorskich w brzmieniu rozporządzenia nr 202 z 27 lutego 2010 r. transponującego dyr. 2001/29.

${ }^{32}$ Powołano tu cyt. wyżej wyrok w sprawie L'Oréal i in. (pkt 64).

${ }^{33}$ Wyrok z 1 grudnia 2011 r. w sprawach połącz. C-M446/09 i C-M495/09, Philips i Nokia (pkt 57 i 78).
} 
sprzedaży podrobionych zegarków doszło drogą wysyłkową za pomocą strony internetowej z państwa trzeciego, nie może pozbawiać firmy Rolex ochrony wynikającej z ww. rozporządzenia. Zegarki te były bowiem przeznaczone dla klienta w UE. I nie ma tu znaczenia, czy były one przed tą sprzedażą przedmiotem oferty lub reklamy w UE.

Przedstawiony wyrok pokazuje, że wskazane jest przeniesienie na grunt prawa autorskiego, w kwestii zakresu prawa do rozpowszechniania utworu, reguł dotyczących ochrony innych praw własności intelektualnej, w szczególności prawa do znaku. Przemawia za tym potrzeba zapewnienia uprawnionym do tego rodzaju praw w UE jednakowej ochrony prewencyjnej z regulacji celnej o egzekwowaniu takich praw względem podróbek towarów.

\section{ODNIESIENIE POWYŻSZEGO PROBLEMU DO PRAWA POLSKIEGO}

W prawie polskim problem ten podlega ocenie na tle kilku przepisów łącznie $^{34}$. Wynika z nich, że uprawnionemu do utworu przysługuje prawo korzystania z niego, w szczególności przez jego rozpowszechnianie, które polega na publicznym udostępnianiu w jakikolwiek sposób, w tym przez wprowadzenie do obrotu droga przeniesienia własności, a ponadto przez publiczne wykonanie, wystawienie, wyświetlenie, odtworzenie, nadawanie, reemitowanie i udostępnianie każdemu w dowolnym miejscu i czasie (art. $17 \mathrm{w} \mathrm{zw}$ z art. 6 ust. 1 i 3 oraz art. 50 pkt 2-3 prawa autorskiego ${ }^{35}$ ). W porównaniu z normami innych państw, zwłaszcza tymi z opisanych wyżej spraw, przepisy te sa uboższe ${ }^{36}$. Paradoksalnie mogłyby one tu wydawać się mniej „kłopotliwe” w kontekście rozważanego dylematu. Nie niosa za sobą w zestawieniu z art. 4 ust. 1 dyr. 2001/29 - jak jest to w przypadku norm niemieckich czy duńskich - wprost kwestii, czy prawo do utworu obejmuje ofertę sprzedaży lub reklamę. Nie wymieniają explicite tego rodzaju sfer wyłączności, niemniej kwestia taka tu powstaje. Na ich tle nie jest oczywiste, czy oferta lub reklama dotyczaca utworui to nie tylko wtedy, gdy nie doszło jeszcze do przeniesienia własności oryginału lub kopii - stanowi naruszenie prawa do utworu.

Stanowisko wynikajace z przedstawionego orzecznictwa Trybunału jest wiążace w prawie polskim. Prawo to jest bowiem podporządkowane zarówno dyr. 2001/29, jak i TPA, a także podlega interpretacji czyniącej zadość celom unijnych norm egzekucyjnych w dziedzinie praw własności intelektualnej, a więc dyr. 2004/48 i rozp. 608/2013. Wzgląd na te cele przemawia za rozumieniem pojęcia rozpowszechniania utworu w zgodzie z pojęciami, którymi

\footnotetext{
${ }^{34}$ Jest to ów „zlepek” norm krajowych wspomniany przez rzecznika w sprawie Donner.

${ }^{35}$ Ustawa z 4 lutego 1994 r. o prawie autorskim i prawach pokrewnych, t.jedn.: Dz. U. 2006, Nr 90, poz. 631 ze zm.

${ }^{36} \mathrm{~W}$ wielu systemach krajowych prawo rozpowszechniania utworu jest określone m.in. jako oferta sprzedaży lub udostępnianie w celu wprowadzenia do obrotu. Zob. G. Westkamp, The Implementation of Directive 2001/29/EC in the Member States, na: http://www.ivir.nl/publications/ guibault/InfoSoc_Study_2007.pdf.
} 
w prawie polskim określa się odpowiadające ww. pojęciu sfery wyłączności podmiotów innych praw własności intelektualnej, a więc z pojęciem używania znaku towarowego lub korzystania z wzoru przemysłowego czy opatentowanego wynalazku (art. 154 pkt 1 i 3 oraz art. 105 ust. 2-3, a także art. 66 ust. 1 w zw. z art. 63 ust. 1 p.w.p.). Rzecz jasna, taka koherencja w wykładni pojęcia prawa do rozpowszechniania utworu może uwzględniać jedynie te przejawy eksploatacji znaku, wzoru czy wynalazku, które nie tylko polegają na sprzedaży lub są nastawione na przeniesienie własności towarów zawierających ww. rozwiązania albo przynajmniej mają związek z taką transakcja lecz które zarazem mają miejsce w przestrzeni publicznej. Równocześnie działania te muszą być skierowane do odbiorców utworu w Polsce.

\section{UWAGA KOŃCOWA}

Przedstawiony problem pokazuje, że w dziedzinie prawa autorskiego, zwłaszcza w dobie komunikacji elektronicznej, nie ma zagadnień, na które istnieją oczywiste odpowiedzi. Kwestie, które prima vista wydają się proste, okazują się faktycznie dylematami. Co więcej, dylematy te, nawet rozstrzygnięte w orzecznictwie Trybunału, powracają w postaci nowych pytań uwarunkowanych stanem faktycznym początkowo niebranym pod uwagę lub widzianym z innej perspektywy. Pokazuje to wyrok w sprawie Peek\&Cloppenburg, mający podstawowe znaczenie w sprawie Dimensione Direct Sales. Tylko w tym wyroku chodziło bowiem o rozumienie pojęcia rozpowszechniania utworu „w inny sposób” niż przez sprzedaż. I pomimo odrzucenia w nim rozciagnięcia tego pojęcia na inne działania niż te, które skutkują przeniesieniem własności, oraz uzależnienia takiej możliwości od woli prawodawcy, to przy okazji kolejnych spraw okazało się, że pojęcie to musi - dla zapewnienia efektywności ochrony prawa autorskiego - brać pod uwagę kontekst rynkowy takich działań i obejmować cała sferę mających z nimi związek czynności. Poza tym, pomimo że następnie rzecznik w sprawie Donner wyłączył z takiej sfery reklamę (nawet tę odpowiadająca ofercie) przy świadomości jej przynależności do zakresu innych praw własności intelektualnej, np. prawa do znaku, to z kolei rzecznik w sprawie Dimensione Direct Sales (po części na podstawie wyniku sprawy Blomqvist) uwzględnił reklamę jako formę rozpowszechniania chronioną prawem autorskim, i to bez specjalnego podpierania się regulacją o znakach. Pomijając odczucie, że sposób interpretacji prawa autorskiego, jeśli nie w ogóle prawa własności intelektualnej, jest często bardziej skomplikowany niż sama jego litera, to pouczające jest śledzenie przebijania się orzecznictwa przez meandry, tworzone $\mathrm{w}$ realiach obrotu prawnego przez desygnaty pojęć opisanych tą literą.

dr hab. Marcin Trzebiatowski

Profesor Katolickiego Uniwersytetu Lubelskiego Jana Pawła II remigius@kul.pl 


\title{
AN OFFER AND AN ADVERTISEMENT AS FORMS OF DISSEMINATION OF A WORK IN LIGHT OF ARTICLE 4 CLAUSE 1 OF DIRECTIVE 2001/29/EC - OBVIOUSNESS OR A DILEMMA?
}

\author{
Sum mary
}

The concept of 'any form of public dissemination' of work 'by way of sale or otherwise' referred to in Article 4 clause 1 of Directive 2001/29/EC was initially interpreted by the ECJ rather narrowly, and merely excluded situations where the transfer of ownership of work had not been finalised. In the judgment in Peek\&Cloppenburg, such approach was adopted only with regards the transfer of ownership, leaving the use of a reproduction of a protected work, and its public exposure in particular, subject to a provision 'made accessible to the public through a sale' included in WIPO treaties on copyright, artistic performances and phonograms.

A change came with the judgment in Donner, where the ECJ ruled that the above concept required an independent construction in the European Union law, i.e. one that would apply to transactions within which dissemination took place and which would be distinct from a sale in the meaning of civil law provisions, rather taking into account the prevailing market conditions. Thus each transaction directed upon providing access to and availability of reproductions of protected works, including advertisements informing of the form of delivery or supplies of reproductions and forms of payment thereof was treated as dissemination.

This new concept became fully-fledged after the judgment delivered in Blomqvist which contained interpretation of the concept 'using in commercial transactions' taken from the EU provisions on trademarks, as well as a regulation sanctioning enforcement of IP rights protection. At the same time it concerned interpretation of the above concept in connection with a concept 'using in commercial transactions' contained in the EU provisions on trademarks, as well as the regulation on the enforcement of the protection of intellectual property by customs bodies. Recognising the identity of the above concepts, the CJEU ruled that if, pursuant to a national law of a Member State, protection of work from public availability includes its protection against 'public dissemination' as well as 'a sale, lease or use of a reproduction of work is offered, or where they are publicly disseminated otherwise' all these activities must be considered as disseminating work even if the work originates in a state where such protection is not granted.

Thus the opinion voiced by the General Ombudsman in Dimensione Direct Sales, who allowed inclusion of a statement of an infringement of the binding law prohibiting dissemination of work also in the event of an actual absence of sale if only a transaction prohibited by provisions of that law lies within a context clearly conducive to making a contract. Such interpretation is justified as authors must be ensured effective control over commercialisation of their works starting from reproduction through trading (circulation) to the exhaustion of copyright.

The concept of using work referred to in Article 17 in connection with Article 6 clause 1 and 3 and Article 50 point 2-3 should be construed likewise. 
